\title{
TRABALHO, RIQUEZA E NATUREZA HUMANA: MARX E A CRÍTICA AO MODO DE PRODUÇÃO CAPITALISTA
}

\author{
WORK, WEALTH AND HUMAN NATURE: MARX AND THE CRITIC OF CAPITALISM
}

\author{
Vitor Bartoletti Sartori*
}

\begin{abstract}
RESUMO
Pretendemos demonstrar que, ao mesmo tempo em que Marx não traz uma crítica ao modo de produção capitalista a partir de certa valorização acrítica do trabalho, ele enxerga como essencial a transformação substantiva da produção material. Um elogio ao trabalho, e ao trabalho produtivo, antes de ser uma posição marxiana, é aquela de autores como Smith e Locke, de tal modo, a rigor, que não há na crítica marxiana algo como uma centralidade do trabalho. No presente texto, assim, procuraremos trazer à tona a compreensão marxiana da relação entre trabalho, riqueza e natureza humana, diferenciando a posição marxiana daquela burguesa. Explicitaremos a defesa marxiana de uma individualidade multifacetada e de indivíduos universalmente desenvolvidos.
\end{abstract}

PALAVRAS-CHAVE: Marx. Trabalho. Riqueza. Natureza humana.

\section{ABSTRACT}

In this article, we intend to demonstrate that, even thought Marx does not criticize the capitalist mode of production from a certain uncritical appreciation of labor, he sees as essential the substantive transformation of material production. An acritical compliment to work, and to productive work, before being a Marxian position, is that of authors like Smith and Locke. There is no Marxist criticism from the standpoint of the centrality of work. In this text, we will try to bring to light the Marxian understanding of the relation between work, wealth and human nature, differentiating the Marxian position from that of bourgeois thinkers. We will explain the Marxian defense of a multifaceted individuality and of universally developed individuals.

KEY-WORDS: Marx. Work. Wealth. Human Nature.

\section{INTRODUÇÃO}

Ao se tratar da teoria marxiana, não é incomum certa ênfase dada à noção de trabalho, que, não só seria central ao autor, mas também conformaria um parâmetro normativo a ser trazido à tona. Neste artigo, a partir daquilo que o filósofo brasileiro José Chasin chamou de análise imanente ${ }^{1}$, procuraremos tratar dos meandros da questão ao abordar, simultaneamente,

\footnotetext{
* Doutor em Filosofia do direito pela USP e mestre em História pela PUC SP. Professor de hermenêutica na Faculdade de Direito da UFMG. E-mail: vitorbsartori@gmail.com.

${ }^{1}$ Como aponta José Chasin: "tal análise, no melhor da tradição reflexiva, encara o texto - a formação ideal - em sua consistência autosignificativa, aí compreendida toda a grade de vetores que o conformam, tanto positivos como negativos: o conjunto de suas afirmações, conexões e suficiências, como as eventuais lacunas e incongruências que o perfaçam. Configuração esta que em si é autônoma em relação aos modos pelos quais é encarada, de frente ou por vieses, iluminada ou obscurecida no movimento de produção do para-nós que é
} 
e em correlação com o tema, a temática da riqueza e da natureza humana. Tratar-se-á de enfatizar, na obra marxiana, as tensões e contradições que aparecem na tematização do trabalho em meio ao modo de produção capitalista. Nossa análise, claro, não esgota a questão, mas traremos seus delineamentos essenciais. Procuraremos, com isso, demonstrar que mesmo que seja necessário, como querem autores como Ricardo Antunes (2009), que se considere o caráter ineliminável da mediação do homem com a natureza, isso não redunda em qualquer ênfase exagerada na definição da crítica ao capitalismo a partir de uma forma de trabalho não estranhada. Intentamos trazer à tona também que, embora seja necessário reconhecer que, para Marx, a produção material conforma o "reino da necessidade", isso não leva o autor a desconsiderar a dialética existente entre as condições de trabalho, a diminuição da jornada de trabalho e o florescimento daquilo que chama de "riqueza real da sociedade".

\section{TRABALHO E RIQUEZA SOCIAL: REINO DA NECESSIDADE E DA LIBERDADE}

Quanto colocamos a questão desse modo, desde já, é preciso destacar que o tema não é simples como normalmente se supõe. Na Crítica ao programa de Gotha, o próprio Marx foi enfático no sentido de que sequer toda a riqueza advém do trabalho, ao contrário do que muitos socialistas pensavam (e pensam): "o trabalho não é a fonte de toda riqueza. A natureza é a fonte dos valores de uso (e é em tais valores que consiste propriamente a riqueza material!), tanto quanto o é o trabalho, que é apenas a exteriorização (Äußerung) de uma força natural, da força de trabalho humana" (MARX, 2012, p. 24). O autor alemão, assim, afirma seu materialismo no sentido de trazer algo óbvio: a utilidade daquilo que é produzido depende, em grande parte, das propriedades naturais presentes em cada ente. Ao mesmo tempo, ressalta algo que já destacava desde 1844: o modo pelo qual o homem se coloca, ao mesmo tempo, como ser social e natural. Se o trabalho é uma exteriorização de uma "força natural", continua a posição marxiana dos Manuscritos de Paris segundo a qual "o homem é imediatamente ser natural. Como ser natural, e como ser natural vivo, está, por um lado, munido de forças naturais, de forças vitais" (MARX, 2004. p. 127). ${ }^{2}$ Assim, destaca-se justamente a alteridade do ser social diante da natureza, já que, como apontou o autor em $O$ capital, "ao atuar, por

elaborado pelo investigador, já que, no extremo e por absurdo, mesmo se todo o observador fosse incapaz de entender o sentido das coisas e dos textos, os nexos ou significados destes não deixariam, por isso, de existir [...]". (CHASIN, 2009, p. 26)

${ }^{2}$ Aqui não poderemos tratar da questão da eventual divisão da obra marxiana em fases. Em diversos momentos, porém, procuraremos demonstrar que há em passagens de 1844 e do final da vida do autor uma unidade bastante visível. 
meio desse movimento, sobre a Natureza externa a ele e ao modificá-la, ele modifica, ao mesmo tempo, sua própria natureza" (MARX, 1996a, p. 297). ${ }^{3}$ Ou seja, por mais que a conformação de algo como a Natureza externa e a natureza humana seja distinta, elas desenvolvem-se em correlação, de maneira que, não obstante as determinações objetivas e externas da primeira em oposição às determinações sociais da segunda, ambas só podem ser vistas em correlação, de modo que mesmo a "Natureza externa", muito embora traga determinações objetivas, não é somente algo dado e desvinculado da mediação da atividade humana. Ao tratar da "prioridade da natureza exterior" (MARX; ENGELS, 2007, p. 31), Marx vem a apontar, contra Feuerbach, que:

Essa diferenciação [entre Natureza externa e interna (V.B.S)] só tem sentido na medida em que se considerem os homens como distintos da natureza. De resto, essa natureza que precede a história humana não é a natureza na qual vive Feuerbach; é uma natureza que hoje em dia, salvo talvez em recentes formações de ilhas de corais australianas, não existe mais em lugar nenhum e, portanto, também não existe para Feuerbach. (MARX; ENGELS, 2007, p. 32).

Com isso, dizemos que o enfoque no trabalho traz o fato de que o homem é, de acordo com Marx, um ser autoposto, autoprodutor que, em correlação com a natureza externa, transforma também a si mesmo, a sua própria natureza. Com isso, porém, não afirmamos que a atividade produtiva seja o centro da atividade humana obrigatoriamente. Não obstante ela seja insuprimível, e sobre isso Marx é explícito, tal qual Bacon, ela não deixa de trazer à tona certa necessidade de adequação à natureza externa. Ao enfatizar a "atividade humana sensível" (MARX; ENGELS, 2007), e não só o trabalho, Karl Marx diz o oposto sobre o comunismo, por exemplo, quando, em $O$ capital, trata de criticar a centralidade, nas sociedades classistas, da atividade material mesma:

A riqueza real da sociedade e a possibilidade de constante expansão de seu processo de produção não depende, portanto, da duração do mais-trabalho, mas de sua produtividade e das condições mais ou menos ricas de produção em que ela transcorre. O reino da liberdade só começa, de fato, onde cessa o trabalho

\footnotetext{
${ }^{3} \mathrm{Na}$ passagem completa, aponta Marx: “antes de tudo, o trabalho é um processo entre o homem e a Natureza, um processo em que o homem, por sua própria ação, media, regula e controla seu metabolismo com a Natureza. Ele mesmo se defronta com a matéria natural como uma força natural. Ele põe em movimento as forças naturais pertencentes a sua corporalidade, braços e pernas, cabeça e mão, a fim de apropriar-se da matéria natural numa forma útil para sua própria vida. Ao atuar, por meio desse movimento, sobre a Natureza externa a ele e ao modificá-la, ele modifica, ao mesmo tempo, sua própria natureza. Ele desenvolve as potências nela adormecidas e sujeita o jogo de suas forças a seu próprio domínio. Não se trata aqui das primeiras formas instintivas, animais, de trabalho. $\mathrm{O}$ estado em que o trabalhador se apresenta no mercado como vendedor de sua própria força de trabalho deixou para o fundo dos tempos primitivos o estado em que o trabalho humano não se desfez ainda de sua primeira forma instintiva. Pressupomos o trabalho numa forma em que pertence exclusivamente ao homem." (MARX, 1996a, p. 297-298).
} 
determinado pela necessidade e pela adequação a finalidades externas; portanto, pela própria natureza da questão, isso transcende a esfera da produção material propriamente dita. Assim como o selvagem tem de lutar com a Natureza para satisfazer suas necessidades, para manter e reproduzir sua vida, assim também o civilizado tem de fazê-lo, e tem de fazê-lo em todas as formas de sociedade e sob todos os modos de produção possíveis. Com seu desenvolvimento, amplia-se esse reino da necessidade natural, pois se ampliam as necessidades; mas, ao mesmo tempo, ampliam-se as forças produtivas, que as satisfazem. Nesse terreno, a liberdade só pode consistir em que o homem social, os produtores associados, regulem racionalmente esse seu metabolismo com a Natureza, trazendo-o para seu controle comunitário, em vez de serem dominados por ele como se fora por uma força cega; que o façam com o mínimo emprego de forças e sob as condições mais dignas e adequadas à sua natureza humana. Mas este sempre continua a ser um reino da necessidade. Além dele é que começa o desenvolvimento das forças humanas, considerado como um fim em si mesmo, o verdadeiro reino da liberdade, mas que só pode florescer sobre aquele reino da necessidade como sua base. A redução da jornada de trabalho é a condição fundamental. (MARX, 1986, p. 273).

A "riqueza real da sociedade" não advém do trabalho somente, mas do modo mediado pelo qual se conformam as forças produtivas, cuja base real está na relação entre homem e natureza, embora nunca se possa reduzir a questão a este último ponto. Trazer certa "centralidade ao trabalho" traz um duplo aspecto: ao mesmo tempo, destaca-se que o trabalho concreto é um elo intermediário imediato entre a sociedade e a natureza: "antes de tudo, o trabalho é um processo entre o homem e a Natureza, um processo em que o homem, por sua própria ação, media, regula e controla seu metabolismo com a Natureza" (MARX, 1996a, p. 297). Simultaneamente, tem-se que esse processo pode ter inúmeras figuras, sendo que aquela específica da sociedade civil-burguesa traz o processo produtivo como algo que se impõe aos indivíduos como uma potência opressiva e estranhada:

Tanto na agricultura quanto na manufatura, a transformação capitalista do processo de produção aparece, ao mesmo tempo, como martirológio dos produtores, o meio de trabalho como um meio de subjugação, exploração e pauperização do trabalhador, a combinação social dos processos de trabalho como opressão organizada de sua vitalidade, liberdade e autonomia individuais. (MARX, 1998b, p. 131).

Ou seja, na sociedade civil-burguesa, é central o trabalho também ao passo que o processo produtivo se impõe objetivamente aos indivíduos "como opressão organizada de sua vitalidade, liberdade e autonomia individuais." Para Marx, por outro lado, trata-se de, suprimindo o modo de produção capitalista, superar tal centralidade e tal caráter impositivo da produção, em que, em uma espécie de inversão da própria realidade (produzida pela atividade humana), o valor "passa continuamente de uma forma para outra, sem perder-se nesse movimento, e assim se transforma num sujeito automático" (MARX, 1996a, p. 273). Para o autor, com a superação do modo de produção capitalista, é mais que necessária a redução da 
jornada de trabalho, o que conflui com o desenvolvimento da produtividade em uma forma de sociabilidade que se coloque como superior àquela do capital e em que, apontam Marx e Engels (1998, p. 45), "o desenvolvimento livre de cada um é a condição para o desenvolvimento livre de todos". O homem é um ser, também, natural, no entanto, somente de modo imediato. Reduzi-lo a esse aspecto seria desconsiderar o próprio processo em que "ao atuar, por meio desse movimento, sobre a Natureza externa a ele e ao modificá-la, ele modifica, ao mesmo tempo, sua própria natureza” (MARX, 1996ª p. 149).

Assim, a questão se delineia de tal maneira que é bom que perceba que a riqueza material não decorre somente do processo produtivo capitalista, mas da transformação dos valores de uso, algo que é possível (e muito mais harmonioso) em outros modos de produção mais desenvolvidos, em que se trata de superar a oposição entre cidade e campo, figura em que tanto no meio urbano como no rural tem-se degradação: sob a produção da grande indústria, "ela destrói simultaneamente a saúde física dos trabalhadores urbanos e a vida espiritual dos trabalhadores rurais" (MARX, 1996b, p. 131-132). Tem-se, assim, uma segunda forma de estranhamento do homem diante da natureza (LUKÁCS, 2013); não mais aquela forma em que a natureza aparece como uma potência estranha e externa, mas aquela em que “a produção capitalista só desenvolve a técnica e a combinação do processo de produção social na medida em que solapa os mananciais de toda a riqueza: a terra e o trabalhador" (MARX, 2013, p. 703). Ou seja, depois de determinado grau de desenvolvimento das forças produtivas, a autonomia individual, bem como os "mananciais de toda a riqueza", "a fonte dos valores de uso (e é em tais valores que consiste propriamente a riqueza material!), tanto quanto o [...] o trabalho", são aviltadas pelo processo produtivo capitalista. Marx, assim, destaca que a produção material não pode ser suprimida, de modo algum. No entanto, a reprodução da vida, com o desenvolvimento das forças produtivas - e, para Marx, "a apropriação dessas forças não é em si mesma nada mais do que o desenvolvimento das capacidades individuais correspondentes aos instrumentos materiais de produção" (MARX; ENGELS, 2007, p. 73) - deixa de demandar os mesmos tempo e energia, de tal maneira que é possível diminuir ao mínimo o tempo de trabalho socialmente necessário para a produção material propriamente dita. Assim, pode-se trazer um processo produtivo que se dê "com o mínimo emprego de forças e sob as condições mais dignas e adequadas à sua natureza humana." Ou seja, com a supressão do modo de produção capitalista, trata-se de retirar de campo a centralidade do processo de produção material da vida, de tal feita que seja possível buscar, não só uma forma racional do "reino da necessidade", mas "o desenvolvimento das 
forças humanas, considerado como um fim em si mesmo, o verdadeiro reino da liberdade, mas que só pode florescer sobre aquele reino da necessidade como sua base."

\section{PROLETARIADO, NATUREZA E CRÍTICA AO TRABALHO}

A riqueza, portanto, não advém do trabalho somente ("a natureza é a fonte dos valores de uso"); tem-se, com isso, em verdade, que o processo de produção material, que traz, até certo ponto, "o trabalho determinado pela necessidade e pela adequação a finalidades externas", pode e, segundo Marx, deve ocupar uma parcela bastante menor do tempo disponível socialmente. Marx aponta tal questão tendo em conta a relação entre "reino da necessidade" e "da liberdade", colocada pela necessidade de supressão do modo de produção capitalista e, como vimos, da imposição do processo produtivo sobre as individualidades. O autor diz também que, tanto o "selvagem" quanto o "civilizado" precisam reproduzir sua vida, sendo impossível suprimir a existência da natureza externa. Ao mesmo tempo, na esteira do que dissemos sobre a relação entre Natureza externa e desenvolvimento da sociabilidade e da atividade humana sensível, há sempre de se destacar que Marx é explícito nos Grundrisse: "fome é fome, mas a fome satisfeita com carne cozida e comida com garfo e faca é diferente da fome daquele que devora carne crua, com ajuda das mãos, das unhas e dos dentes" (MARX, 1993, p. 92). Isso implica, sempre, a relativa autarquia da natureza externa - ao contrário do que colocaram importantes autores como Alfred Schmidt (1977) -, que se coloca como externa ao próprio homem ao mesmo tempo em que, já neste aspecto "natural", tem-se a impossibilidade do indivíduo mônada: "a fome é uma carência natural; ela necessita, por conseguinte, de uma natureza fora de si, de um objeto fora de si, para se satisfazer, para se saciar. A fome é a carência confessada de meu corpo por um objeto existente fora dele, indispensável à sua integração e externação essencial” (MARX, 2004, p. 127). A questão é de enorme relevo.

Uma sociedade comunista, segundo Marx, supera o problema da fome e do pauperismo colocando uma forma de sociabilidade que não tem o tempo de trabalho socialmente necessário, relacionado à "duração do mais-trabalho", como medida, mas o tempo livre; mas, claro, isso, segundo o autor de $O$ capital, decorre da própria superação da escassez com o fim do capitalismo, supõe que "forças produtivas também tiverem crescido e todas as fontes da riqueza coletiva jorrarem em abundância” (MARX, 2012, p. 32). Se é verdade que, no campo da produção material, “a liberdade só pode consistir em que o homem 
social, os produtores associados, regulem racionalmente esse seu metabolismo com a Natureza, trazendo-o para seu controle comunitário, em vez de serem dominados por ele como se fora por uma força cega", Marx trata do comunismo como a supressão das potências estranhas desenvolvidas pelo capital e defende uma regulação racional da atividade produtiva. Porém, também tem em mente a redução do tempo dedicado ao metabolismo imediato com a "natureza externa", de modo que tal metabolismo continua sempre sendo a base real da atividade dos homens, mas, cada vez mais, a sua atividade não se reduz à relação entre o homem e a Natureza externa. Ou seja, se a relação imediata do homem se dá com a Natureza externa por meio do trabalho, as inúmeras mediações que se colocam em meio ao desenvolvimento da sociabilidade - relacionado ao incremento das forças produtivas, das capacidades individuais - fazem com que a produção material possa ser, objetiva e efetivamente, trazida à tona, não de modo impositivo (como uma espécie de "sujeito automático") mas como a base real, que nunca pode ser suprimida, ao mesmo tempo em que se torna, cada vez mais, somente algo como uma base de sustentação. Diz Marx sobre o "reino da necessidade": "além dele é que começa o desenvolvimento das forças humanas, considerado como um fim em si mesmo, o verdadeiro reino da liberdade, mas que só pode florescer sobre aquele reino da necessidade como sua base".

Os homens, assim, teriam transformado suas próprias naturezas a tal ponto que a esfera da produção material propriamente dita deixaria de se impor por meio de um processo produtivo totalizante, que coloca os homens como portadores de relações sociais estranhadas. Trata-se, assim, da supressão da situação em que o homem, por meio da venda da sua força de trabalho, coloca-se como um apêndice do processo produtivo. Trata-se, em Marx, da supressão do capital, ou seja, de uma relação social que procura reproduzir-se, em meio ao assalariamento, como valor que gera valor e que se impõe sobre o desenvolvimento individual e da natureza social dos homens.

Que é, pois, o valor da força de trabalho? Como o de toda outra mercadoria, esse valor se determina pela quantidade de trabalho necessário para produzi-la. A força de trabalho de um homem consiste, pura e simplesmente, na sua individualidade viva. Para poder crescer e manter-se, um homem precisa consumir uma determinada quantidade de meios de subsistência; o homem, como a máquina, se gasta e tem que ser substituído por outro homem. (MARX, 1996b, p. 378).

No valor da força de trabalho, o homem coloca-se tal qual uma máquina; ou seja, objetivamente, sua existência é reificada em meio ao processo de reprodução do capital. A sua individualidade viva é submetida a uma forma de sociabilidade que "reflete a relação social 
dos produtores com o trabalho total como uma relação social existente fora deles, entre objetos. Por meio desse quiproquó os produtos do trabalho se tornam mercadorias, coisas físicas metafísicas ou sociais" (MARX, 1996a, p. 198). Assim, a oposição entre trabalho e capital - inerente ao modo de produção capitalista e relacionada à figura do trabalho assalariado - traz consigo a imposição de certa centralidade do processo produtivo diante dos homens. Esse processo parece ter uma existência fantasmagórica e invertida, em que o capital aparece - somente ao passo que nunca pode ser efetivamente um sujeito - como uma espécie de "sujeito automático". Com isso, segundo Marx, tem-se que a riqueza real da sociedade só pode ser trazida, não com o trabalho como fonte de valor, mas com a necessidade de supressão da própria lei do valor, esta última que, de acordo com o autor de $O$ capital, traz consigo a imposição de uma medida objetiva à existência do processo produtivo, o tempo de trabalho socialmente necessário. Nesse sentido, da oposição entre trabalho e capital, Marx não traz um elogio unilateral ao trabalho - que, aqui, não é mais somente "um processo em que o homem, por sua própria ação, media, regula e controla seu metabolismo com a Natureza", mas aquele que se conforma como a outra face do capital, o trabalho produtor de mercadorias, e, assim, "o corpo da mercadoria que serve de equivalente figura sempre como corporificação do trabalho humano abstrato e é sempre o produto de determinado trabalho concreto, útil. Esse trabalho concreto torna-se portanto expressão de trabalho humano abstrato" (MARX, 1996a, p. 185).

Dessa oposição, tem-se a necessidade da supressão das classes sociais e, com elas, do trabalho que se caracteriza como determinação reflexiva diante do capital, o trabalho assalariado. Nesse sentido, diz Marx algo bastante importante ao ter em conta o caráter reificado de tal processo:

Os proletários, para afirmar a si mesmos como pessoas, têm de suprassumir (aufheben) sua própria condição de existência anterior, que é, ao mesmo tempo, a condição de toda a sociedade anterior, isto é, o trabalho. Eles também se encontram, por isso, em oposição ao Estado, a forma pela qual os indivíduos se deram, até então, uma expressão coletiva, e têm de derrubar o Estado para impor a sua personalidade. (MARX; ENGELS, 2007, p. 66).

Para se afirmarem enquanto pessoas contra uma existência reificada em que, em meio ao trabalho assalariado e à circulação de mercadorias, tem-se "determinada relação social entre os próprios homens que para eles aqui assume a forma fantasmagórica de uma relação entre coisas" (MARX, 1996 b, p. 198), é necessário que os proletários suprimam aquilo que os caracteriza como tais, o assalariamento. Ou seja, Marx, desde a Ideologia alemã, mas o 
mesmo se mantém em $O$ capital, como visto, trata de um tema que lhe será central em suas obras durante toda a sua vida: aquele relativo ao modo pelo qual a personalidade dos homens é aviltada em meio à reprodução diuturna da relação-capital. Para o que tratamos aqui, também surge algo essencial: os termos que Marx usa na frase deixam claro, primeiramente, que não é toda a atividade que se confunde com o trabalho - o que ele, segundo Vieira (2017), já apontava em seus Manuscritos econômico-filosóficos - e, depois: que não há de se temer a afirmação de que é necessário, ao fim, suprimir o trabalho. Claro, isso se dá ao passo que há um trabalho específico a se suprimir, aquele que se coloca como outro polo do capital, o trabalho assalariado, que é a condição da sociedade anterior àquela em que se supera a existência das classes sociais. Marx, na passagem, refere-se a "toda a sociedade anterior", de modo que, inclusive, busca a superação (nunca a supressão) daquilo que acima mencionamos como o reino da necessidade, relacionado à produção material propriamente dita. Temos que perceber, no entanto, que a superação que Marx trata aqui (na tradução acima a palavra está como suprassunção, relacionada ao alemão Aufhebung) não poderia nunca significar a supressão da própria atividade produtiva, mas, como visto acima, a redução de sua centralidade na sociedade e a sua transformação substancial. Falar da supressão do trabalho, portanto, só pode significar a supressão do trabalho assalariado. A atividade produtiva sempre é "reino da necessidade", mas a liberdade, mesmo que tenha significado distinto, também aparece nessa esfera: "nesse terreno, a liberdade só pode consistir em que o homem social, os produtores associados, regulem racionalmente esse seu metabolismo com a Natureza, trazendo-o para seu controle comunitário, em vez de serem dominados por ele como se fora por uma força cega". Ou seja, trata-se de suprimir o trabalho estranhado, para que se use a dicção de 1844 (MARX, 2004), o trabalho abstrato e a lei do valor, para que remetamos à obra $O$ capital.

Mesmo que não possamos tratar do tema aqui, há de se perceber que, em Marx, a afirmação da individualidade dos indivíduos não prescindiria também da supressão do Estado, que, até o final de sua vida, é visto como uma "excrescência parasitária colocada à sociedade civil-burguesa", e é um "pesadelo sufocante" (MARX, 2011b, p. 126). Para o que nos diz respeito aqui, há de se tirar algumas conclusões: primeiramente, percebe-se que, muito embora Marx tome como insuprimível a relação entre o homem e a natureza, ele se coloca contra o modo pelo qual tal relação se dá na sociedade capitalista. Sua crítica se posiciona, também, contra a conformação objetiva do trabalho nesse modo de produção, não se tratando de um elogio à atividade produtiva, ou à classe que a realiza mormente, o proletariado. Em 
segundo lugar, nota-se que o autor de $O$ capital se direciona contra a centralidade que adquire o processo produtivo no modo de produção capitalista, procurando justamente uma forma de sociabilidade em que se reduz ao mínimo o "reino da necessidade", ao mesmo tempo em que este último pode tomar uma forma racional e planejada; em terceiro lugar, é preciso ter claro que se tem uma crítica ao próprio assalariamento e ao trabalho que se caracteriza como na relação-capital, e não uma crítica a uma forma de assalariamento específica.

\section{NATUREZA HUMANA E AFIRMAÇÃO DA INDIVIDUALIDADE NO COMUNISMO}

Não se trata, assim, de superar uma forma de trabalho assalariado, mas de suprimir o próprio assalariamento, que conforma uma relação estranhada, contrária ao "desenvolvimento das forças humanas, considerado como um fim em si mesmo, o verdadeiro reino da liberdade." Marx, portanto, passa longe de se apoiar em alguma moral proletária (que supõe a defesa da preservação de um dos polos da relação-capital). Tem-se, assim, uma crítica ao trabalho que se conforma em oposição ao capital e se coloca como determinação reflexiva deste. Não obstante a supressão da moderna sociedade civil-burguesa se dê, segundo Marx, passando pela oposição entre trabalho e capital, ou seja, entre o proletariado e a burguesia modernos, pelo que vemos, é muito importante ter em conta que o autor elabora sua teorização buscando a supressão das classes sociais mesmas, e não só da burguesia. Ou seja, a concepção de comunismo marxiana não é, e nem pode ser, relacionada à universalização da forma assalariada, do proletariado, ou do trabalho abstrato:

\footnotetext{
A classe possuinte e a classe do proletariado representam a mesma autoalienação (Selbstentfremdung) humana. Mas a primeira das classes se sente bem e aprovada nessa autoalienação, sabe que a alienação é seu próprio poder e nela possui a aparência de uma existência humana; a segunda, por sua vez, sente-se aniquilada nessa alienação, vislumbra nela sua impotência e a realidade de uma existência desumana. Ela é, para fazer uso de uma expressão de Hegel, no interior da abjeção, a revolta contra essa abjeção, uma revolta que se vê impulsionada necessariamente pela contradição entre sua natureza humana e sua situação de vida, que é a negação franca e aberta, resoluta e ampla dessa mesma natureza. (MARX; ENGELS, 2003, p. 48).
}

O estranhamento (Entfremdung) - acima traduzido como alienação - não diz respeito, de acordo com Marx, a uma classe social, mas à conformação objetiva do ser social em que se tem o antagonismo entre determinadas classes, no caso da moderna sociedade civil-burguesa, essencialmente, entre a burguesia e o proletariado (embora seja essencial para a compreensão das diversas formações sociais ter em mente vários meandros relacionados aos antagonismos 
entre diversas outras classes sociais e embora deva-se sempre ter em conta que, para Marx, nunca é verdade que as outras classes que não o proletariado são simplesmente reacionárias: “elas não formam, portanto, juntamente com a burguesia, uma só massa reacionária” (MARX, 2012, p. 35). Ou seja, o assalariamento mesmo, uma figura particular do processo de trabalho, um modo específico pelo qual se tem a mediação da produção material, é a fonte do estranhamento nesse caso. Como diz Marx (1980, p. 582):

\begin{abstract}
a produção capitalista baseia-se na contraposição entre dois fatores, o trabalho materializado e o trabalho vivo, o capitalista e o trabalho assalariado são os únicos funcionários e fatores da produção cujas relações e antinomia provêm da natureza do modo capitalista de produção.
\end{abstract}

Isso, porém, dá-se de tal modo que, de um lado, tem-se a "aparência de uma existência humana", doutro lado, com a moderna classe trabalhadora, a possibilidade de, diante da impotência figurada no assalariamento, ter-se a "realidade de uma existência humana" que poderia buscar romper com a contraposição mesma mencionada acima.

Tal aspecto não pode deixar de remeter àquilo que Marx chamou, em $O$ capital, de "desenvolvimento das forças humanas, considerado como um fim em si mesmo"; outro aspecto importante que remete à mencionada passagem da obra magna do autor alemão é a referência à noção de natureza humana e, para Marx, "a história não é mais que uma transformação contínua da natureza humana" (MARX, 1985, p. 138). Em A sagrada família, trata-se da abjeção diante da "negação franca e aberta" dessa mesma natureza, ao passo que, posteriormente, ter-se-á a referência a uma esfera da produção material em que seja posta pela atividade produtiva "com o mínimo emprego de forças e sob as condições mais dignas e adequadas à sua natureza humana." É importante destacar aqui, porém, não só a continuidade entre o "jovem Marx" e o "Marx maduro", passando por textos que vão de 1844 até o final da vida de Marx, mas destacar que o pensamento marxiano, explicitamente, deixa de trazer a posição do proletariado como um parâmetro, por assim dizer, normativo ou ético. Antes, o autor de $O$ capital, em passagens decisivas, vem a mencionar uma categoria que, não raro, foi vista como dotada de uma carga essencialmente idealista, aquela de "natureza humana". Ela traz determinações do ser social e é histórica e objetiva e, desse modo, remete ao processo objetivo pelo qual se tem o incremento das capacidades individuais.

Pelo que dissemos aqui, tal categoria remete ao modo pelo qual o homem, ao transformar a realidade, transforma a si mesmo. Ou seja, tem-se a objetividade e a historicidade do ser social colocadas em tal categoria, e não um apelo anti-histórico e 
hipostasiado. Aqui não podemos aprofundar a questão de modo cuidadoso, infelizmente (a respeito ver MARKUS, 2015). Mas vale destacar que somente com um processo de trabalho em que "o homem social, os produtores associados, regulem racionalmente esse seu metabolismo com a Natureza, trazendo-o para seu controle comunitário, em vez de serem dominados por ele como se fora por uma força cega" tem-se um sociometabolismo que permite, por parte dos trabalhadores, a superação da "contradição entre sua natureza humana e sua situação de vida" e isso, como já mencionado, só poderia acontecer ao se suprimir o próprio assalariamento, a própria conformação do trabalho enquanto determinação reflexiva do capital:

O proletariado na condição de proletariado, de outra parte, é obrigado a suprassumir a si mesmo e com isso à sua antítese condicionante, aquela que o transforma em proletariado: a propriedade privada. Esse é o lado negativo da antítese, sua inquietude em si, a propriedade privada que dissolve e se dissolve. (MARX; ENGELS, 2003, p. 48).

Em A Sagrada família, diz Marx que se trata da superação da propriedade privada, compreendida com cuidado, o que, o autor demonstra posteriormente, significa a supressão da propriedade privada dos meios de produção, que está na raiz do assalariamento. Tem-se, claro, pois: deve-se, em meio a essa relação social específica, suprimir tanto o trabalho do proletariado quando o proletariado mesmo, que, como já coloca o autor alemão desde cedo, aparece como uma característica sui generis diante de outras classes já que, ao superar as condições que sustentam sua miséria, precisa superar a própria sociedade que dá base a essas condições e, com isso, as próprias classes sociais: "uma classe com grilhões radicais, de uma classe da sociedade civil[-burguesa] que não seja uma classe da sociedade civil[-burguesa]" (MARX, 2005, p. 156). Neste sentido, tem-se nada menos que necessidade da supressão da "pré-história da sociedade humana" (MARX, 2009, p. 48), em que o desenvolvimento do indivíduo não acompanha o desenvolvimento da riqueza de um modo de produção baseado no antagonismo classista, sendo que, segundo Marx, "a riqueza das sociedades em que domina o modo de produção capitalista aparece como uma 'imensa coleção de mercadorias' e a mercadoria individual como sua forma elementar" (MARX, 1996a, p. 165). Ou seja, trata-se de suprimir tal modo de conformação da riqueza que se oponha ao desenvolvimento da "riqueza real da sociedade e a possibilidade de constante expansão de seu processo de produção". 
Com isso, trata-se, não de trazer a centralidade do trabalho e do processo produtivo, mas de enfocar no modo pelo qual, sob "o reino da necessidade", e da própria produção material, mas para além dele, "que começa o desenvolvimento das forças humanas, considerado como um fim em si mesmo, o verdadeiro reino da liberdade, mas que só pode florescer sobre aquele reino da necessidade como sua base." Para que os proletários se afirmem como pessoas diante da imposição do processo produtivo, portanto, trata-se de suprimir o próprio assalariamento e, com ele, o trabalho que se coloca como uma determinação reflexiva do capital. Com isso, porém, supera-se o proletariado moderno como tal. No lugar do aviltamento das individualidades, "no lugar da sociedade civil-burguesa [bürgerliche Gesellchaft] antiga, com suas classes e antagonismos de classe, teremos uma associação na qual o desenvolvimento livre de cada um é a condição para o desenvolvimento livre de todos" (MARX; ENGELS, 1998, p. 45). Trata-se de superar a oposição existente entre o desenvolvimento genérico e comunitário de um lado, e o individual doutro.

\section{RIQUEZA, NATUREZA HUMANA E TRANSFORMAÇÃO SUBSTANTIVA DO TRABALHO}

Compreender isso só é possível ao se ter em conta a crítica de Marx à própria riqueza da sociedade capitalista, que, simultaneamente, aparece como um simples fruto do trabalho (abstrato) e como uma "imensa coleção de mercadorias". Quando trazemos isso à tona, temos em conta que a riqueza desta sociedade é produzida com o incremento de forças produtivas e, portanto, de capacidades individuais; ao mesmo tempo, porém, tem-se que justamente tal desenvolvimento traz consigo a oposição entre as individualidades e o processo produtivo. Nesse sentido, Marx aponta que tanto é preciso transformar o processo produtivo quanto retirá-lo de uma posição central em uma sociedade comunista. Mesmo que esse processo seja ineliminável, trata-se de desenvolver uma figura do processo de trabalho que não traz o homem como apêndice da máquina ou como um indivíduo que é subsumido a uma espécie de "sujeito automático". Diz o autor algo muito importante nas Teorias do mais-valor ao remeter tanto à necessidade do trabalho quanto ao modo pelo qual sua figura relacionada ao capital precisa perecer para que se tenha liberdade:

O tempo de trabalho, mesmo anulando-se o valor de troca, permanece sempre a substância criadora da riqueza e a medida do custo que sua produção exige. Mas o tempo livre, o tempo disponível, é a própria riqueza - quer para fruir o produto, quer para a atividade livre, atividade que não é determinada como o trabalho pela coerção de um objetivo externo que é mister, atingir e cuja realização é necessidade natural 
ou dever social como se queira. É evidente que o próprio tempo de trabalho, por se limitar à extensão nominal e além disso não se efetuar mais para outrem e sim para mim mesmo, junto com a remoção dos antagonismos sociais entre patrões e empregados etc., assume, como trabalho realmente social e por fim como base do tempo disponível, caráter de todo diverso, mais livre, e que o tempo de trabalho de um ser humano que é ao mesmo tempo um ser com tempo disponível, terá de possuir qualidade superior ao do trabalho da besta de carga. (MARX, 1980, p. 1306).

Há uma oposição entre "a substância criadora de riqueza" - que se coloca no trabalho, mais precisamente no trabalho abstrato nas sociedades capitalistas, o trabalho socialmente necessário para a reprodução do capital - e a própria riqueza, relacionada ao tempo livre, na sociedade capitalista, ao tempo disponível, muito embora haja uma dependência objetiva frente à produção ligada à transformação da natureza como trabalho concreto, mas não abstrato e estranhado em uma sociabilidade colocada para além do capital. Ou seja, ao trazer à tona a questão da riqueza de uma sociedade emancipada, tem-se a emancipação diante da medida objetiva do trabalho socialmente necessário: trata-se da supressão do valor, mas não do tempo de trabalho. É impossível superar o trabalho como tal até mesmo porque este, em relação com a natureza, traz valores de uso, relativos à riqueza material da sociedade e também a "medida de custos", base sobre a qual uma produção material racional e planejada pode se colocar e que, por sua vez, dá sustentação ao "tempo livre, o tempo disponível”, que, emergindo sob a relação do homem com a natureza, "é a própria riqueza".

Com isso, tem-se certa continuidade no que diz respeito àquilo mencionado acima sobre o "reino da necessidade" e o "da liberdade". Há de se notar que Marx não fala na passagem de "trabalho livre", mesmo que postule a necessidade da transformação radical do processo de trabalho. Assim, continua trazendo à tona a posição segundo a qual liberdade, na esfera da produção material, só pode significar “o mínimo emprego de forças e sob as condições mais dignas e adequadas à sua natureza humana" no metabolismo com a natureza que é trazido de modo racional. Dessa maneira, segundo o autor de $O$ capital, "a liberdade só pode consistir em que o homem social, os produtores associados, regulem racionalmente esse seu metabolismo com a Natureza, trazendo-o para seu controle comunitário". Ou seja, há diferença específica entre a liberdade colocada na esfera produtiva e aquela que se coloca para além dela, como "atividade livre"; podemos dizer, assim, que há, em verdade, heterogeneidade entre trabalho e atividade, diferença esta que se mantém de 1844 até as obras mais tardias de Marx (VIEIRA, 2017). E tal ponto deve ser enfatizado pois o autor de $O$ capital menciona, novamente, a questão da relação entre a Natureza externa e a humana remetendo à "atividade livre, atividade que não é determinada como o trabalho pela coerção 
de um objetivo externo". Ou seja, novamente, percebe-se que o papel que a atividade produtiva desempenha no todo social tende a diminuir com o aumento da produtividade e com a emancipação da sociedade diante da lei do valor, mesmo que se tenha em conta: "para tanto, porém, se requer uma base material da sociedade ou uma série de condições materiais de existência, que, por sua vez, são o produto natural de uma evolução histórica longa e penosa" (MARX, 1996a, p. 204). Assim, a mediação do homem com a natureza é ineliminável e constitua a base sobre a qual se erguem quaisquer modos de produção. Com o comunismo, porém, trata-se de aumentar o campo do "reino da liberdade" diante do "reino da necessidade", mesmo que o primeiro tenha por base o segundo.

A questão tem seus meandros, certamente. De acordo com Marx, a exteriorização (Äusserung) presente no trabalho é diferente da atividade livre: ao tratar desta última, tem-se "a atividade livre, atividade que não é determinada como o trabalho pela coerção de um objetivo externo". Ou seja, ao passo que o trabalho traz sempre, até certo ponto, a sujeição à Natureza externa e a um objeto externo, sob a base da atividade produtiva, pode emergir a atividade livre. $\mathrm{O}$ trabalho traz consigo um afastamento de barreiras naturais, certamente; mas nunca a supressão destas (LUKÁCS, 2013). E, com isso, tem-se algo essencial à compreensão de nosso tema: a transformação no processo de produção é essencial, ao mesmo tempo em que se coloca no "reino da necessidade". A "necessidade natural" e o "dever social", até certo ponto, e somente até certo ponto, confundem-se na produção material. No entanto, o trabalho mesmo muda substancialmente com a supressão do capital. Trata-se da supressão do trabalho que se conforma em oposição ao capital, do trabalho assalariado. Novamente, aqui, é essencial ressaltar que, para tudo isso, "a redução da jornada de trabalho é a condição fundamental." Ou seja, Marx não coloca o trabalho como central no comunismo, mas, como este nunca pode deixar de ser a base da sociabilidade do homem, há uma necessidade imperativa de uma transformação efetiva de sua figura. Trata-se da superação do trabalho como o conhecemos até hoje na história das sociedades marcadas pelo antagonismo classista. A produção, então, não tem mais por medida o tempo de trabalho socialmente necessário, mas o tempo livre e, com isso, os indivíduos não são mais submetidos ao processo produtivo, mas o contrário. Marx diz que "na história que se deu até aqui é sem dúvida um fato empírico que os indivíduos singulares, com a expansão da atividade numa atividade histórico-mundial, tornaram-se cada vez mais submetidos a um poder que lhes é estranho" (MARX; ENGELS, 2007, p. 41). Trata-se da supressão dessa situação e, para isso, é necessária a mudança substantiva na própria produção. 
Na esfera produtiva, com a supressão do modo de produção capitalista, o tempo de trabalho deixa de ser realizado para outrem ao passo que se tem "a remoção dos antagonismos sociais entre patrões e empregados etc.," e, com isso, o processo produtivo "assume, como trabalho realmente social e por fim como base do tempo disponível, caráter de todo diverso, mais livre". Ou seja, ao mesmo tempo, Marx admite que trabalho e atividade são essencialmente distintos e traz à tona uma defesa bastante clara da necessária transformação no processo de trabalho. A questão muda de face em uma sociedade emancipada, também, porque se tem a produção de riqueza com base no "tempo de trabalho de um ser humano que é ao mesmo tempo um ser com tempo disponível." Trata-se do trabalho que, sempre, "terá de possuir qualidade superior ao do trabalho da besta de carga." A questão é fundamental para a compreensão da obra marxiana. Com ela, percebemos, simultaneamente, que o autor traz a heterogeneidade entre trabalho e atividade livre, mas não se furta de mostrar que ambas as formas de atividade humana sensível só se conformam em correlação e sem que se possa falar da riqueza de uma sociedade sem a análise cuidadosa da correlação necessária existente entre ambas as figuras da atividade humana.

Ou seja, no campo da produção, tem-se, com a supressão das sociedades classistas, "produtores associados, [que] regulem racionalmente esse seu metabolismo com a Natureza, trazendo-o para seu controle comunitário, em vez de serem dominados por ele como se fora por uma força cega" e, sob este "reino da necessidade" substancialmente transformado e controlado de forma racional e consciente, emerge o desenvolvimento dos "indivíduos universalmente desenvolvidos, cujas relações sociais, como relações próprias e comunitárias, estão igualmente submetidas ao seu próprio controle comunitário, não são um produto da natureza, mas da história” (MARX,2011a, p.164). Esses indivíduos, por seu turno, sem as amarras das sociedades classistas, podem se apropriar de suas próprias capacidades, de modo que se tem a possibilidade de uma "associação na qual o desenvolvimento livre de cada um é a condição para o desenvolvimento livre de todos." E nesse ponto é de grande relevo destacar: ao mesmo tempo em que esta última se coloca tendo em conta a heterogeneidade entre o "reino da necessidade" e o "da liberdade", tal associação de "indivíduos universalmente desenvolvidos" só pode ter por base uma forma de produção que não se imponha às individualidades e que, portanto, remeta ao controle comunitário, e não ao processo produtivo como a exteriorização de uma potência estranha, ou seja, como estranhamento. Percebe-se, assim, que o autor de $O$ capital destaca a diferença entre atividade livre e trabalho, mas mostra, ao mesmo tempo, que ambos sempre estão relacionados de modo indissociável. Com 
o trabalho estranhado por base, tem-se somente "a aparência de uma existência humana" e nunca uma forma de sociabilidade em que a atividade livre pode emergir real e efetivamente. A esfera da vida dos homens só pode, pois, colocar-se de modo livre quando, em sua relação com a história, os indivíduos têm em conta que "a figura do processo social da vida, isto é, do processo da produção material, apenas se desprenderá do seu místico véu nebuloso quando, como produto de homens livremente socializados, ela ficar sob seu controle consciente e planejado" (MARX, 1996a, p. 204). Controle consciente, planejado e comunitário da produção material é uma condição sem a qual não se pode ter uma associação de indivíduos universalmente desenvolvidos e emancipados.

\section{RIQUEZA, TRABALHO E NATUREZA HUMANA: MARX E A CRÍTICA DA IDEOLOGIA BURGUESA DO TRABALHO}

Marx, portanto, não realiza propriamente uma crítica ao modo de produção capitalista por este não valorizar o trabalho, e sim o capital. $O$ enfoque marxiano não é este, definitivamente. No entanto, não é possível chegar ao outro polo simplesmente. A partir do que colocamos, vê-se que não há como concordar com autores como Postone (2014) ou Kurz (1993) para quem, in totum, a partir de Marx, só se pode retirar para o presente uma crítica ao trabalho. Isto só é verdade ao se tomar o trabalho como o oposto ao capital, o trabalho assalariado. Por mais que o trabalho continue sempre no "reino da necessidade", o autor alemão é enfático no sentido da necessidade de um controle consciente e planejado do processo de produção material e, portanto, do processo de trabalho. Ou seja, trazer um modo de produção alternativo significa a modificação substantiva do modo pelo qual, primariamente por meio do trabalho, mas não só por ele, os homens transformam sua própria natureza. É necessário, porém, termos um cuidado suplementar: não é porque autores como Postone e Kurz estão equivocados nas consequências que retiram da obra de Marx que é possível trazer o trabalho como central para a sociabilidade que supere a relação-capital. Diz Marx:

\footnotetext{
Numa fase superior da sociedade comunista, quando tiver sido eliminada a subordinação escravizadora dos indivíduos à divisão do trabalho e, com ela, a oposição entre trabalho intelectual e manual; quando o trabalho tiver deixado de ser mero meio de vida e tiver se tornado a primeira necessidade vital; quando, juntamente com o desenvolvimento multifacetado dos indivíduos, suas forças produtivas também tiverem crescido e todas as fontes da riqueza coletiva jorrarem em abundância, apenas então o estreito horizonte jurídico burguês poderá ser plenamente superado e a sociedade poderá escrever em sua bandeira: "De cada um
} 
segundo suas capacidades, a cada um segundo suas necessidades!”. (MARX, 2012, p. 33).

Trazer o trabalho como central significaria permanecer ligado a uma sociabilidade em que o trabalho é um "mero meio de vida"; ou seja, novamente vale destacar: Marx está atacando justamente a sociedade que faz com que os homens apareçam como personificações de relações sociais estranhadas, mesmo que isso signifique que os homens, em meio aos antagonismos sociais, apareçam como representantes do "trabalho", como "trabalhador coletivo", em oposição ao capital. Como já mencionado, nem mesmo o moderno proletariado é elevado a um patamar elogioso e acrítico por Marx, estando essa classe social embebida do mesmo autoestranhamento que a burguesia, mesmo que tenha uma posição substancialmente distinta diante desse estranhamento. Algo essencial neste momento é a colocação marxiana segundo a qual, no comunismo, o trabalho não é suprimido, aparecendo como "primeira necessidade vital"; ou seja, diante do desenvolvimento das forças produtivas, tem-se o desenvolvimento das individualidades, o "desenvolvimento multifacetado dos indivíduos" de tal modo que a riqueza aparece como coletiva, e não por meio da apropriação privada e da forma mercantil, indissociáveis das formas jurídicas (PACHUKANIS, 2017). Marx, portanto traz o trabalho como um elemento insuprimível da sociabilidade como tal, ao mesmo tempo em que valoriza o processo no qual se torna possível que "todas as fontes de riqueza coletiva jorrem em abundância", de tal modo que se torna anacrônica uma sociabilidade centrada no processo imediato de produção e no trabalho abstrato. No que é interessante notar que Marx, na passagem, traz também uma crítica ao "estreito horizonte jurídico burguês". E, em verdade, tal concepção, segundo o próprio autor, está baseada em uma teorização em que o trabalho é central:

A concepção de Locke é da maior importância porque é a expressão clássica das ideias jurídicas da sociedade burguesa em oposição a feudal, e além disso sua filosofia serviu de base a todas as ideias desenvolvidas por toda a economia inglesa posterior. (MARX, 1980, p. 356).

Locke, em verdade, traria a legitimação da apropriação privada por meio da valorização do trabalho. E, nesse sentido, não há como deixar de apontar que, ao seguirmos aquilo colocado por Marx, algo como a valorização do "fruto integral do trabalho" (trazido à tona pelo socialismo estatal lassaliano, que Marx critica em sua Crítica ao programa de Gotha) está muito mais próximo das "ideias jurídicas da sociedade burguesa em oposição a feudal" que do moderno socialismo. Veja-se como que a questão da propriedade aparece em 
Locke, em sua teorização sobre o "estado de natureza" - absolutamente distinta da concepção marxiana de natureza, que trouxemos acima. Para o autor inglês, a natureza, de início, é de posse comum aos homens, mas tal situação se modifica substancialmente pelo trabalho que, ao adicionar algo à natureza, legitima a propriedade privada:

\begin{abstract}
Ainda que a terra e todas as criaturas inferiores pertençam em comum a todos os homens, cada um guarda a propriedade de sua própria pessoa; sobre esta ninguém tem qualquer direito, exceto ela. Podemos dizer que o trabalho de seu corpo e a obra produzida por suas mãos são propriedade sua. Sempre que ele tira um objeto do estado em que a natureza o colocou e deixou, mistura nisso o seu trabalho e a isso acrescenta algo que lhe pertence, por isso o tornando sua propriedade. Ao remover este objeto do estado comum em que a natureza o colocou, através do seu trabalho adiciona-lhe algo que excluiu o direito comum dos outros homens. Sendo este trabalho uma propriedade inquestionável do trabalhador, nenhum homem, exceto ele, pode ter o direito ao que o trabalho lhe acrescentou, pelo menos quando o que resta é suficiente aos outros, em quantidade e em qualidade. (LOCKE, 1994, p. 98).
\end{abstract}

Há de se notar a relação direta estabelecida pelo autor inglês entre o Direito, a "propriedade de sua pessoa" (que podemos relacionar, em verdade, na sociedade capitalista, à propriedade da mercadoria força de trabalho), e a propriedade privada que "excluiu o direito comum dos outros homens". Nisto, nota-se que, se há alguma ideologia que coloca o trabalho como central e como fonte de toda a riqueza, e que, com isso, traz uma espécie de "força sobrenatural de criação" (MARX, 2012, p. 24), essa ideologia é aquela da burguesia. Se é verdade que essa mesma burguesia, em meio ao desenvolvimento das contradições da sociedade capitalista, será forçada a abandonar este ponto de vista (MARX, 1980), isso não leva, segundo Marx, os comunistas a precisarem adotá-lo; antes, em verdade, seria preciso notar que o próprio modo de pensar burguês já é anacrônico, sendo preciso uma compreensão mais cuidadosa da relação entre homem e natureza.

Nesse sentido, a valorização do trabalho faz parte da ideologia burguesa ao passo que se coloca contra a sociedade feudal e absolutista em que eram abundantes aquilo que Adam Smith chamava de "classes improdutivas", classes que não se colocavam diretamente relacionadas à produção material propriamente dita. Nesse sentido, Adam Smith, tal qual Locke, vai valorizar o trabalho, mais precisamente o "trabalho produtivo". E, nesse ponto, vale destacar: tal qual Marx não traz exatamente um elogio do trabalho, não o traz quanto ao trabalho produtivo, até mesmo porque, segundo o autor, "trabalho produtivo portanto é o que no sistema de produção capitalista produz mais-valia para o empregador ou que transforma as condições materiais de trabalho em capital e o dono delas em capitalista, por conseguinte trabalho que produz o próprio produto como capital" (MARX, 1980, p. 391). Ou seja, pelo 
que colocamos, em verdade Marx defende a supressão do trabalho produtivo, do trabalho que gera valor, colocando-se contra o capital como um todo. Novamente, nesse ponto vale destacar: não é Marx que se coloca como "produtivista”, mas o próprio sistema capitalista cujos porta-vozes progressistas trouxeram uma valorização do trabalho.

Não podemos tratar a fundo da questão do trabalho produtivo em Marx (ver COTRIM, 2013). No entanto, podemos afirmar que, a rigor, no sentido mais preciso, o autor de $O$ capital é um crítico do trabalho produtivo, sendo a concepção burguesa, como a de Smith, aquela que traz um elogio a esta forma de trabalho. Aqui, vale apontar que, tanto Smith quanto Locke, traziam elementos claramente ligados à burguesia em ascensão. Smith, com a crítica às “classes improdutivas", traz uma crítica à sociabilidade feudal; já Locke, ao tratar da apropriação pelo trabalho, sempre ressalta que o direito de propriedade decorrente do trabalho dos indivíduos somente poderia se colocar enquanto "pelo menos quando o que resta é suficiente aos outros, em quantidade e em qualidade.” Ou seja, a filosofia política bem como a economia política clássicas traziam a posição da burguesia ascendente e que ainda acreditava ser portadora do desenvolvimento social e do bem-estar de todas as classes sociais. No entanto, Marx é explícito quanto à questão no sentido de que ela iria se modificar, dando lugar a uma posição "apologética" e "vulgar":

\begin{abstract}
A sociedade burguesa passa a produzir, em sua própria forma, tudo que combatera na forma feudal ou absolutista. Tarefa principal dos sicofantas dessa sociedade, sobretudo os dos "níveis mais altos" é portanto, em primeiro lugar, restaurar no plano teórico o segmento meramente parasitário desses "trabalhadores improdutivos" ou ainda justificar as exigências exageradas da fração para ela indispensável. Proclamou-se, na realidade, a dependência das classes ideológicas etc. para com os capitalistas. (MARX, 1980, p. 154).
\end{abstract}

Ou seja, a própria ideologia burguesa do trabalho é, até certo ponto, e somente até certo ponto, deixada de lado na sociedade capitalista, de modo que a burguesia é levada a adotar exatamente a perspectiva que havia combatido. Depois de determinado momento, inclusive, a teorização séria do trabalho produtivo é deixada de lado e, segundo Marx, chegase ao absurdo em que "por fim, também o boi é um trabalhador produtivo" (MARX, 1980, p. 245). Sendo incapaz de defender uma posição que relacione propriedade e trabalho (até mesmo porque crescem na sociedade civil-burguesa as "classes ideológicas", bem como o capital financeiro, por exemplo), vê-se confrontada por sua própria ideologia, mas em outra figura: vê-se diante daquilo que aparece nos primórdios do movimento (imaturo) dos trabalhadores e, posteriormente, nos socialistas que, segundo Marx, no limite, colocam-se, 
depois de determinado grau de desenvolvimento social, como vulgares. Ou seja, novamente, é essencial destacar: a ênfase unilateral no trabalho está mais próxima da burguesia que da posição defendida pelo autor de $O$ capital. Veja-se, novamente, Locke:

\begin{abstract}
Quando Deus deu o mundo em comum a toda a humanidade, também ordenou que o homem trabalhasse, e a penúria de sua condição exigia isso dele. Deus e sua razão ordenaram-lhe que submetesse a terra, isto é, que a melhorasse para beneficiar sua vida, e, assim fazendo, ele estava investindo uma coisa que lhe pertencia: seu trabalho. Aquele que, em obediência a este comando divino, se tornava senhor de uma parcela de terra, a cultivava e a semeava, acrescentava-lhe algo que era sua propriedade, que ninguém podia reivindicar nem tomar dele sem injustiça. Nenhum outro homem podia se sentir lesado por esta apropriação de uma parcela de terra com o intuito de melhorá-la, desde que ainda restasse bastante, de tão boa qualidade, e até mais que indivíduos ainda desprovidos pudessem utilizar. Se bem que, na realidade, a cerca que um homem colocasse em seu benefício não reduziria nunca a parte dos outros. Deixar uma quantidade igual que outro homem fosse capaz de utilizar, equivaleria a não tomar nada. Ninguém pode se sentir lesado por outra pessoa beber, ainda que em uma quantidade exagerada, se lhe é deixado todo um rio da mesma água para matar sua sede. O que vale para a água, vale da mesma forma para a terra, se há quantidade suficiente de ambas. (LOCKE, 1994, p. 101).
\end{abstract}

Marx aponta a origem da ideologia jurídica burguesa em Locke; como já mencionamos "é a expressão clássica das ideias jurídicas da sociedade burguesa em oposição a feudal". E é interessante notar que neste autor inglês aparece o trabalho como portador de "força sobrenatural de criação", inclusive, relacionada à figura divina cristã. É bom destacar para nosso tema que, tal qual no programa de Gotha, em Locke, a riqueza aparece como tendo fonte no trabalho, sendo a relação histórica e social do trabalho com a natureza deixada de lado, ao menos no que toca um estudo cuidadoso e detido que ultrapasse o âmbito religioso e do senso comum. Enquanto Marx critica a concepção estática de Natureza externa e de natureza humana, Locke justamente naturaliza a relação de produção capitalista ao trazer à tona a equação entre apropriação da natureza pelo trabalho, propriedade privada e riqueza. $\mathrm{O}$ autor inglês, inclusive, vem a dizer que, diante da abundância da natureza, desde que houvesse suficiente em quantidade e qualidade para os outros, mesmo a apropriação em "quantidade exagerada" seria plenamente justificável. Uma grande injustiça, portanto, seria reivindicar para si aquilo que outrem teria trazido como fruto do trabalho. Ou seja, se formos ser rigorosos, a noção de "fruto integral do trabalho", de Lassale e presente no programa de Gotha, também sob este aspecto - mesmo que tendo em conta os trabalhadores e não o protótipo do indivíduo burguês -, está mais próxima da ideologia burguesa que da crítica contundente à sociedade capitalista e, por isso, o autor de $O$ capital é tão incisivo. Na crítica ao mencionado programa, inclusive, Marx é muito duro diante da concepção segundo a qual 
toda a riqueza advém do trabalho, como vimos acima. Ele, inclusive, acrescenta algo que vai ao encontro do que estamos desenvolvendo neste momento. Sobre a relação entre burguesia e trabalho, diz:

\begin{abstract}
Os burgueses têm excelentes razões para atribuir ao trabalho essa força sobrenatural de criação; pois precisamente do condicionamento natural do trabalho segue-se que o homem que não possui outra propriedade senão sua força de trabalho torna-se necessariamente, em todas as condições sociais e culturais, um escravo daqueles que se apropriaram das condições objetivas do trabalho. Ele só pode trabalhar com sua permissão, portanto, só pode viver com sua permissão. (MARX, 2012, p. 24).
\end{abstract}

Exatamente a concepção criticada por Marx é aquela que é defendida por Locke, sendo que este autor traz uma concepção que "é a expressão clássica das ideias jurídicas da sociedade burguesa". O autor do Segundo tratado sobre o governo civil é explícito ao apontar que os indivíduos originariamente só possuem seu trabalho, sua "pessoa" e, ao mesmo tempo, com referência ao deus católico, compreende o autor inglês a natureza como algo que está à disposição e que, ao ser transformada pelo trabalho, torna-se propriedade dos indivíduos. Assim, aquilo que Locke naturaliza, ao fim, é a posição segundo a qual, em verdade, tem-se a apropriação privada das "condições objetivas de trabalho", de tal maneira que cada indivíduo só pode trabalhar com permissão do proprietário dos meios de produção. É preciso que se perceba: o programa de Gotha procura defender a apropriação coletiva dos meios de produção, mas, ao permanecer no terreno burguês no que toca o Direito e o trabalho, vem a seguir com base em suposições que naturalizam o modo de produção capitalista, como a existência do assalariamento, ou seja, daquilo que é a contraparte necessária da relação-capital. Para Marx, portanto, não basta realizar um exercício em que, por assim dizer, inverte-se Locke. Antes, trata-se de compreender que o elogio unilateral ao trabalho é próprio da ideologia burguesa, de modo que não se trata de buscar o "fruto integral do trabalho", não só porque "'fruto do trabalho' é uma noção vazia, posta por Lassalle no lugar de conceitos econômicos determinados" (MARX, 2012, p. 28). Isso se dá também porque Marx é explícito na necessidade de supressão do próprio trabalho abstrato, substrato do valor; diz o autor alemão sobre o desenvolvimento do comunismo: "o trabalho transformado em produtos não aparece aqui como valor desses produtos" (MARX, 2012, p. 30), de modo que, em verdade, tem-se uma situação em que é "eliminada a subordinação escravizadora dos indivíduos à divisão do trabalho e, com ela, a oposição entre trabalho intelectual e manual; quando o trabalho tiver deixado de ser mero meio de vida e tiver se tornado a primeira necessidade vital". Ou seja, 
uma concepção que se realize somente do ponto de vista do trabalho abstrato e estranhado seria muito limitada.

A ideologia burguesa - mas também aquele socialismo chamado por Marx de vulgar (MARX, 2012) -, ao valorizar o trabalho, eterniza a divisão do trabalho, bem como o modo pelo qual os indivíduos multifacetados aparecem como escravizados diante dessa divisão. Eles aparecem como portadores de relações sociais estranhadas na sociedade capitalista, como um mero elo na reprodução do capital. Para o autor alemão, por outro lado, trata-se de superar a condição em que o trabalho é um mero meio de vida. Ou seja, o desenvolvimento da "riqueza real da sociedade" passa pela supressão da subordinação dos indivíduos ao processo produtivo, ao mesmo tempo em que a produção mesma (que permanece sempre, até certo ponto no "reino da necessidade") precisa ser modificada substancialmente. Com isso, a posição marxiana é aquela em que, ao contrário do que se dá na ideologia burguesa, a riqueza da sociedade não apareça por meio da apropriação privada e de uma "imensa coleção de mercadorias", mas como "o desenvolvimento das forças humanas, considerado como um fim em si mesmo, o verdadeiro reino da liberdade, mas que só pode florescer sobre aquele reino da necessidade como sua base." Ou seja, segundo o autor de $O$ capital, se o trabalho assalariado avilta a personalidade dos homens, é necessária a supressão deste e a redução ao mínimo da jornada de trabalho, de modo que "o desenvolvimento multifacetado dos indivíduos", bem como os "indivíduos universalmente desenvolvidos", possam tomar o lugar da subordinação da vida dos indivíduos ao processo produtivo do capital. Trata-se do desenvolvimento de um processo de trabalho com "o mínimo emprego de forças e sob as condições mais dignas e adequadas à sua natureza humana" e isso faz com que o trabalho não se imponha ao indivíduo mais como um "mero meio de vida", sendo somente "a primeira necessidade vital". Nela, segundo o autor, está o solo e a base da sociabilidade dos homens, mas, no comunismo, trata-se de valorizar a possibilidade de surgimento de uma forma de riqueza que não se coloque, como nas ideologias burguesas, trazendo o trabalho como central na vida dos homens. Antes, ter-se-ia, até certo ponto, o oposto.

\section{REFERÊNCIAS}

ANTUNES, Ricardo. Os sentidos do trabalho. São Paulo: Boitempo, 2009.

CHASIN, José. Marx: estatuto ontológico e resolução metodológica. São Paulo: Boitempo, 2009.

COTRIM, Vera. Trabalho produtivo em Karl Marx: novas e velhas questões. São Paulo: 
Alameda, 2013.

LOCKE, John. Segundo tratado sobre o governo civil. Tradução Magda Lopes e Maria Lobo da Costa. Petrópolis/RJ: Vozes, 1994.

LUKÁCS, György. Para uma ontologia do ser social II. Tradução Nélio Schneider. São Paulo: Boitempo, 2013.

KURZ, Robert. O colapso da modernização: da derrocada do socialismo de caserna à crise da economia mundial. Tradução Karen Elsabe Barbosa. Rio de Janeiro: Paz e Terra, Brasil, $2^{a}$ edição, 1993.

MARX, Karl. Contribuição à Crítica da economia política. Tradução Florestan Fernandes. São Paulo: Expressão Popular, 2009.

MARX, Karl. Crítica à filosofia do Direito de Hegel - introdução. In: Crítica à filosofia do Direito de Hegel. Tradução Rubens Enderle e Leonardo de Deus. São Paulo: Boitempo, 2005.

MARX, Karl. Crítica ao programa de Gotha. Tradução Rubens Enderle. São Paulo: Boitempo, 2012.

MARX, Karl. Guerra civil na França. Tradução Rubens Enderle. São Paulo: Boitempo, 2011b.

MARX, Karl. Grundrisse. Tradução Mario Duayer. São Paulo: Boitempo, 2011 a.

MARX, Karl. Manuscritos econômico-filosóficos. Tradução Jesus Ranieri. São Paulo: Boitempo, 2004.

MARX, Karl. Miséria da filosofia. Tradução José Paulo Netto. São Paulo: Global, 1985.

MARX, Karl. O capital, Livro I. Tradução Rubens Enderle. São Paulo: Boitempo, 2013.

MARX, Karl. O capital, Livro I, Tomo I. Tradução Regis Barbosa e Flávio R. Kothe São Paulo: Nova Cultural, 1996a.

MARX, Karl. O capital, Livro I, Tomo II. Tradução Regis Barbosa e Flávio R. Kothe São Paulo: Nova Cultural, 1996b.

MARX, Karl. O capital, Livro III, Tomo II. Tradução Regis Barbosa e Flávio R. Kothe São Paulo: Nova Cultural, 1986.

MARX, Karl. Teorias da mais-valia. Tradução Reginaldo Sant'Anna. São Paulo: Civilização brasileira, 1980.

MARX, Karl; ENGELS, Friedrich. Ideologia alemã. Tradução Rubens Enderle. São Paulo: Boitempo, 2007.

MARX, Karl; ENGELS, Friedrich. O manifesto comunista. Tradução Maria Lucia Como. Rio de Janeiro: Paz e Terra, 1998.

MARX, Karl; ENGELS, Friedrich. A Sagrade Família. Tradução Marcelo Backes. São Paulo: 
Boitempo, 2003.

MARKUS, Gyorgy. Marxismo e antropologia: o conceito de "essência humana" na filosofia de Marx. Tradução Rafael Mueller. São Paulo: Expressão Popular; EDIUNESC, 2015.

PACHUKANIS, Evgeni. Teoria geral do Direito e marxismo. Tradução Paula Vaz de Almeida. São Paulo: Boitempo, 2017.

POSTONE. Moishe. Tempo, trabalho e dominação social. Tradução Amilton Reis e Paulo Cezar Castanheda. São Paulo: Boitempo, 2014.

SCHMIDT, Alfred. El concepto de naturaleza em Marx. Tradução Eduardo Pietro. Madrid: Siglo XXI, 1977.

VIEIRA, Maurício Martins. Marx, Spinoza e Darwin, pensadores da imanência. Niterói: Coleção Niepe Marx, 2017. 